\title{
High Voltage Cascaded Step-Up DC-DC Marx Converter for Offshore Wind Energy Systems
}

\author{
S. M. Alagab ${ }^{1}$, S.B. Tennakoon ${ }^{1}$ and C.A. Gould ${ }^{1}$ \\ ${ }^{1}$ SCHOOL OF CREATIVE ARTS AND ENGINEERING, STAFFORDSHIRE \\ UNIVERSITY \\ College Road - Stoke on Trent, ST4 2DE \\ United Kingdom \\ Tel.: +447440012994 \\ E-mail: samir.alagab@research.staffs.ac.uk, S.B.Tennakoon@staffs.ac.uk, \\ C.A.Gould@staffs.ac.uk \\ URL: http://www.Staffs.ac.uk
}

\section{Keywords}

«Emerging technology», «Wind Energy», «Converter circuit», «HVDC», « Multilevel converters », «Soft switching».

\begin{abstract}
This paper presents an improved cascaded DC-DC resonant converter for offshore windfarms. The improvements are reduced losses and the number of components. The topology is based on the Marx principle where charged capacitors are charged in parallel and discharged in series to achieve the voltage transformation. The four inductors of the converter are designed to resonate with the capacitors to create resonance forcing current zeros to enable zero current switching thereby reducing switching losses. The operating principles and design considerations of the proposed converter are discussed and the design equations are presented. In order to evaluate the operation of $50 \mathrm{MW}$ converter aimed at connecting a $30 \mathrm{kV}$ DC Busbar in a wind power collection system to a $360 \mathrm{kV}$ high voltage DC bus for transmission to the onshore grid was simulated and the results are presented.
\end{abstract}

\section{Introduction}

Due to the increased distances to off shore windfarms from the shore, it is expected that the use of High Voltage Direct Current (HVDC) transmission and Medium Voltage Direct Current (MVDC) distribution systems for the grid integration of windfarms will grow worldwide. One of the key components in such systems is the DC-DC converter, required to act as the interface between the generation, transmission and distribution voltage levels [1]. Well-established DC-to-DC converters based on pulse width modulated (PWM) converters, which require high frequency switching, are not suitable. Application to high voltage, high power systems mean series connection of devices and high power losses [2]. Hence, such converters are not technically and economically feasible.

Some converter topologies, which are suitable for high-voltage operation, have been proposed in the literature. Laird [3] and Alagab [1] have proposed suitable step-up converters. The drawback of these converters is the limited voltage gain. The coupled inductor boost converter and cascaded boost converter presented by $\mathrm{Hu}$ [4] and Noui [5] has the advantage of low input current ripple, but its efficiency decreases with increasing power and its switching frequency is high.

Siwakoti, [6], has presented a high step-up DC-DC converter based on a switched coupled inductor arrangement. The converter draws a continuous current from the source, and its voltage gain is controlled by the duty-cycle. A step up resonant converter was introduced by Parastar [7]; the drawback of this converter is the high voltage across the passive components and large power device conduction losses. Modular multilevel converters (MMC) [8]-[9] are proposed for HVDC connected offshore wind 
farms. However, the number of IGBT switches is high. The MMC requires a complex capacitor voltage balancing control scheme.

Recently, the common types of Switched Capacitor Converters (SCC) based on the Marx principle have been considered as an alternative topology. The Marx principle allows the realization of a high voltage gain by connecting the capacitors that are charged in parallel and reconnected in series to discharge. Maneiro [10] presented a shunt HVDC tap using a step down DC to DC converter. This arrangement rquires a large number of IGBT switches.

Veilleux [11,12] DC-DC resonant converter topologies based on the Marx principle, although performs well, the conduction losses are relatively high due to the large number of IGBTs. Improvements were made to reduce the number of IGBTS through a multistage arrangement

\section{Etienne Veilleux Cascaded topology}

As depicted in Fig. 1, there are multi stages of the Marx modules connected in cascade comprising three main sections of input, middle and output section. The middle section consists of three stages, stage 1 , stage 2 , and stage 3 . Stage 1 and stage 3 are identical but the size of the components are different and every stage consists of two capacitors, three switches, two diodes and an inductor. Stage 2 has three capacitors, four switches and three diodes. The overall DC voltage gain is $2 \times 3 \times 2=12,(1: 12)$. In addition, there is an output capacitor at the output stage to smoot the load voltage. The operation can be divided into two sub-commutations.

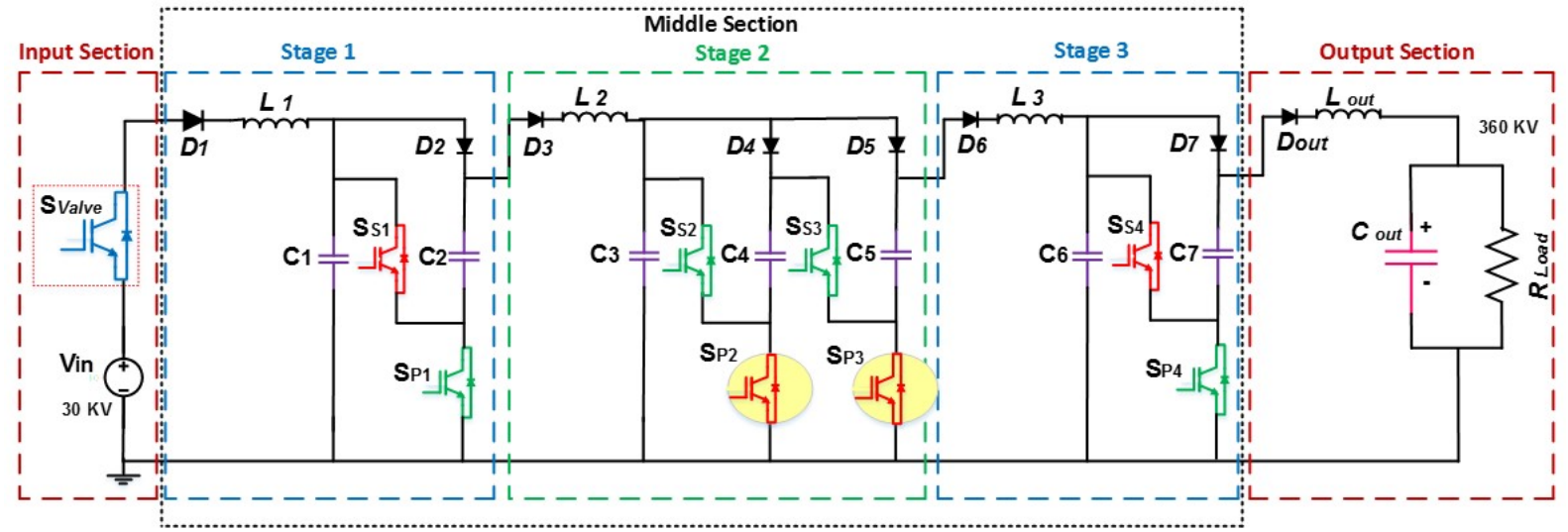

Fig. 1: Veilleux Cascaded Marx DC-DC converter

The charging currents flow through $\mathrm{L}_{1}$ and $\mathrm{L}_{3}$. There are no currents in $\mathrm{L}_{2}$ and $\mathrm{L}_{\text {out. }}$ In the second sub-commutation, capacitors in stages 1 and 3 are connected in series and discharge to stage 2 and the output section respectively. Stage 2 capacitors are connected in parallel during this period. The charging currents flow through $\mathrm{L}_{2}$ and $\mathrm{L}_{\text {out. }}$. There is no current flow in $\mathrm{L}_{1}$ and $\mathrm{L}_{3}$.

The process is repeated periodically transferring the electric charges from the input voltage $V_{\text {in }}$ to the load $\mathrm{R}_{\text {load }}$ via stages 1,2 , and 3. A disadvantage of this topology is the high number of IGBT switches in stage 2 , and the increasing voltage stress in the IGBTs in successive stages.

\section{Proposed topology}

\section{Structure of Cascaded Converter}

The structure of the proposed Cascaded DC-DC converter as depicted in Fig. 2 is derived from the Etienne Veilleux converter by modifying the middle section. The advantage is that the number of components are reduced as shown later in the document and the flexibility for increasing the number of stages in the middle section for increasing the gain. The ratings and the component values used for this study are determined for application to the HV converter in a typical wind energy system [Fig. 6]. Fig. 2 shows the equivalent circuit. The input section consists of an input DC voltage source of magnitude $\mathrm{V}_{\text {in }}=30 \mathrm{kV}$ and $\mathrm{HV}$ valve $\left(\mathrm{S}_{\text {valve }}\right)$ comprising series connected IGBTs. The middle section is composed of three stages; stage 1, stage 2 and stage 3 . The number of capacitors in stages 1, 2 and 3 are set to 2 , 
3 , and 2 respectively to create a voltage amplification of $2 \times 3 \times 2=12$. However, in general, the number of capacitors can be J, K and L respectively and hence; $\mathrm{C}_{\mathrm{J}}, \mathrm{C}_{\mathrm{K}}$ and $\mathrm{C}_{\mathrm{L}}$ indicate the capacitances in the stages 1,2 , and 3 respectively.

The switching components in the middle section denoted by Ssi (i=1-4) are used to connect the capacitors in series. The IGBT switches denoted by $\mathrm{S}_{\mathrm{P}_{\mathrm{i}}}(\mathrm{i}=1-3)$ are used to connect the capacitors in parallel. The diodes are used to trap the charges in the capacitors and to ensure that they discharge in the correct direction. The output section consists of an output diode $\mathrm{D}_{\text {out }}$ connected in series with the output inductor $\mathrm{L}_{\text {out, }}$, and one output capacitor $\mathrm{C}_{\text {out }}$. The load is modeled by a pure resistor $\mathrm{R}_{\text {load. }}$.

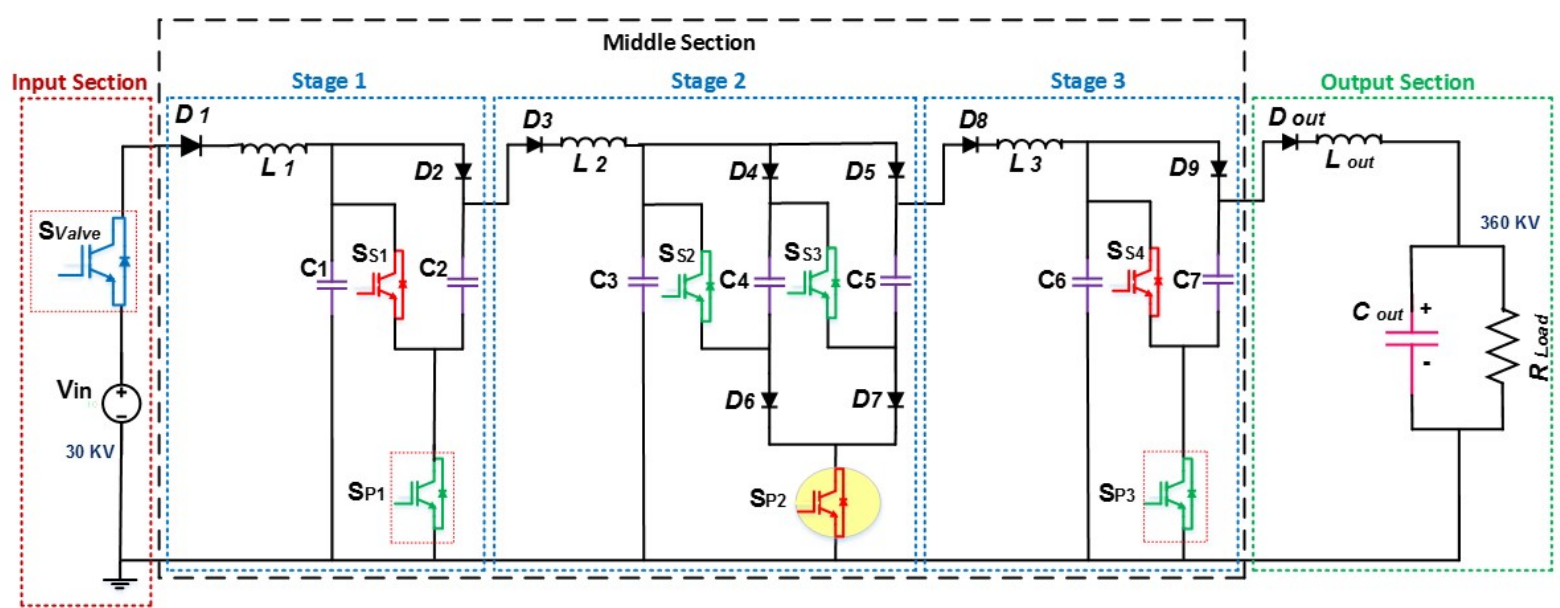

Fig. 2: Improved Cascaded Marx DC-DC Converter

\section{Steady State Operation}

The steady state operation can be explained in terms of two sub-commutations. In simple terms, the IGBTs are switched so that the charges in capacitors are pumped from left to right sequentially resulting in a high voltage at the converter output. The switching of the devices are summarised in Table I. The corresponding sub-circuits are shown in Fig 3 and Fig 4, respectively where the ON and OFF devices are shown in green and light grey, respectively. During the first sub-commutation, capacitors in stages 1 and 3 are connected in parallel and are being charged through the inductors $\mathrm{L}_{1}$ and $\mathrm{L}_{3}$. The capacitors in Stage 2, which have been charged in the previous cycle are in series and discharges into stage 3 capacitors. Diodes $\mathrm{D}_{1}, \mathrm{D}_{2}, \mathrm{D}_{8}$ and $\mathrm{D}_{9}$ conduct.

Table I: IGBT switching logic for the improved converter

\begin{tabular}{|c|c|c|c|c|c|c|c|c|c|c|c|c|c|c|c|c|c|c|}
\hline Switches &  & $\overline{\hat{n}}$ & $\hat{\tilde{n}}$ & $\hat{\tilde{n}}$ & $\bar{n}$ & ஸे & $\tilde{n}$ & 志 & $\overline{0}$ & $\tilde{a}$ & $\stackrel{\varrho}{\rho}$ & $\stackrel{+}{0}$ & ค̊ & $\stackrel{\circ}{0}$ & $\hat{\theta}$ & $\stackrel{\infty}{0}$ &  & $\stackrel{\overline{0}}{\circ}$ \\
\hline $\begin{array}{c}\text { First sub } \\
\text { commutation }\end{array}$ & 1 & 1 & 0 & 1 & 0 & 1 & 1 & 0 & 1 & 1 & 0 & 0 & 0 & 0 & 0 & 1 & 1 & 0 \\
\hline $\begin{array}{l}\text { Second sub } \\
\text { commutation }\end{array}$ & 0 & 0 & 1 & 0 & 1 & 0 & 0 & 1 & 0 & 0 & 1 & 1 & 1 & 1 & 1 & 0 & 0 & 1 \\
\hline
\end{tabular}

In the second sub commutation the devices are switched so that capacitors in stage 1 and 3 and stage 2 are in parallel and series respectively. Hence, capacitors in stages 1 and 3 and 2 are charged and discharged respectively. Repeated switching results in continuous transfer of charge from input side to the output side resulting in a voltage gain of 12, which is equal to the product of number of capacitors $(2 \times 3 \times 2)$ in each stage. The corresponding voltage and current waveforms are given in Fig. 5 


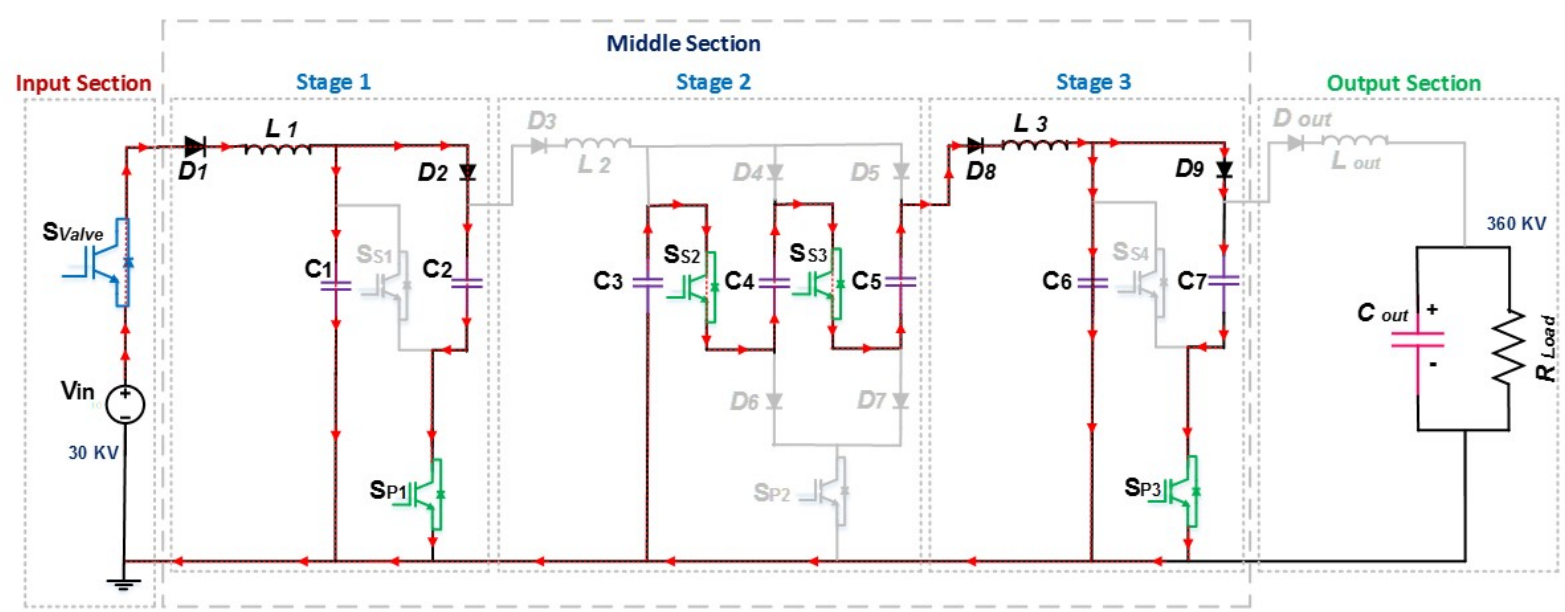

Fig. 3: First sub-commutation configuration

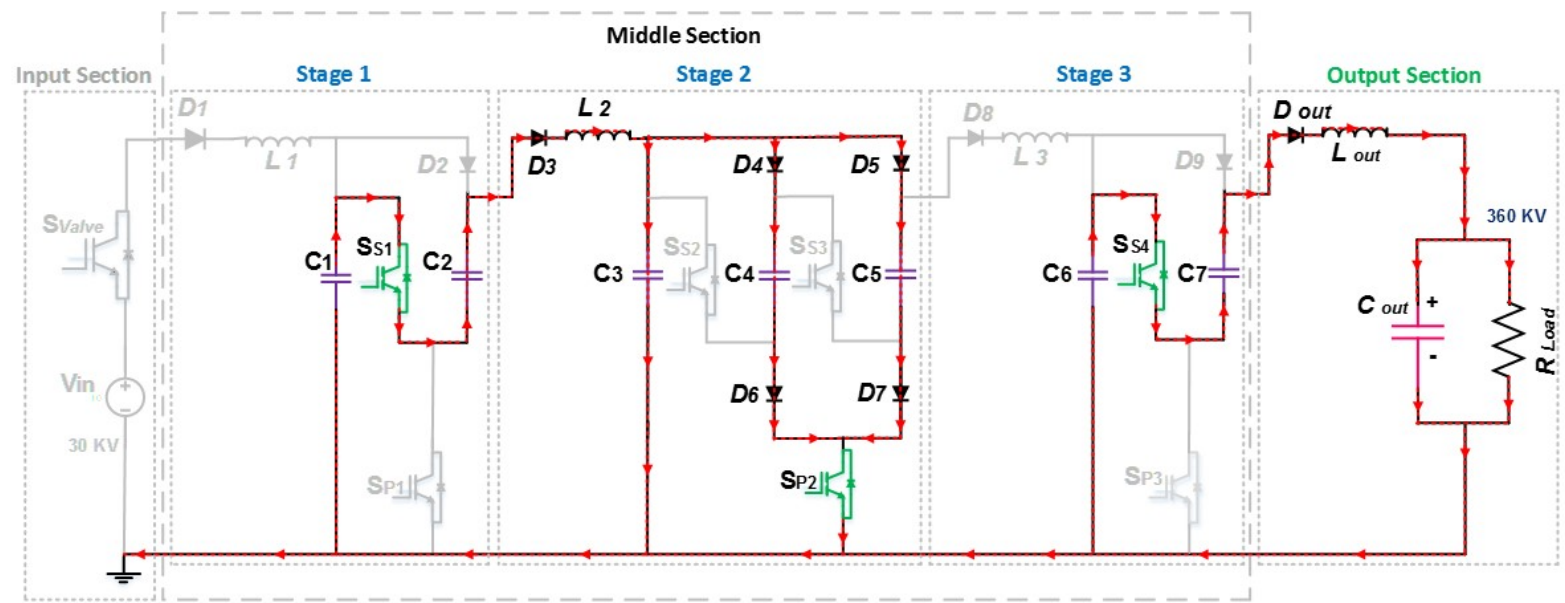

Fig. 4: Second sub-commutation configuration

\section{Generalised analysis of the steady state operation}

It is assumed that the cascaded DC-DC converter has already reached steady state. The gain of the converter is depended on the number of capacitance cells in stage $1(\mathrm{~J})$, stage $2(\mathrm{~K})$, stage $3(\mathrm{~L})$. The voltage transformation ratio $\mathrm{N}$ is given as;

$$
\mathrm{N}=\frac{\mathrm{V}_{\text {out }}}{\mathrm{V}_{\text {in }}}=\mathrm{J} \mathrm{K} \mathrm{L}
$$

where $V_{\text {out }}$ and $V_{\text {in }}$ are the output and input voltages, respectively. The equivalent capacitance in stage 1 is

$$
\mathrm{C}_{\mathrm{eq}(\mathrm{J})}=\sum_{\mathrm{J}=1}^{\mathrm{J}} \mathrm{C}_{\mathrm{j}}
$$

where $\mathrm{C}_{\mathrm{J}}$ is the capacitance, and $\mathrm{C}_{\mathrm{eq}(\mathrm{J})}$ is the equivalent capacitance of parallel connected capacitors in stage 1. During the first-commutation, the inductor $\mathrm{L}_{1}$ and the equivalent capacitance $\mathrm{C}_{\mathrm{eq}(\mathrm{J})}$ forms an oscillatory L-C circuit and hence the current in the stage 1 is given by,

$$
\mathrm{i}_{\mathrm{L} 1}=\mathrm{i}_{\mathrm{Ceq}(\mathrm{J})}=\frac{\mathrm{V}_{\text {in }}}{\omega \mathrm{L}_{1}} \sin (\omega \mathrm{t})
$$

and 


$$
\omega=\frac{1}{\sqrt{\mathrm{L}_{1} \mathrm{C}_{\mathrm{eq}(J)}}}
$$

where $\mathrm{i}_{\mathrm{Ceq}(\mathrm{J})}$ is the current in $\mathrm{C}_{\mathrm{eq}(\mathrm{J})}$. As shown in Fig. 5(a), the peak current in the inductor $I_{L 1}^{P}$ can be deduced form the equation (3);

$$
\mathrm{I}_{\mathrm{L} 1}^{\mathrm{P}}=\mathrm{V}_{\mathrm{in}} \sqrt{\frac{\mathrm{Ceq}(\mathrm{J})}{\mathrm{L}_{1}}}
$$

(a)

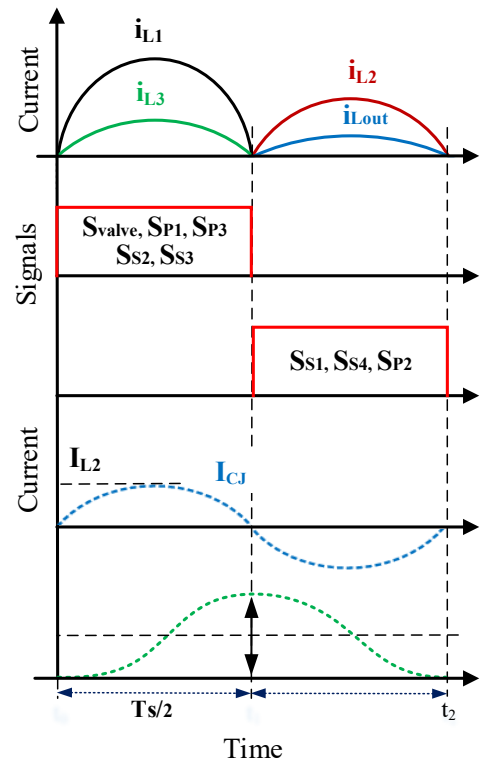

Fig. 5: Ideal steady state waveforms

In order to achieve soft switching, the IGBTs must be switched at the resonant frequency of the inductor current waveform. Therefore, the switching frequency can be written as;

$$
\mathrm{F}_{\mathrm{S}}=\frac{1}{2 \pi \sqrt{\mathrm{L}_{1} \mathrm{C}_{\mathrm{eq}(J)}}}
$$

\section{Determination of stage 1 parameters}

The charge transferred to the capacitors in stage 1 can be expressed as;

$$
\mathrm{Q}=\mathrm{I}_{\mathrm{AV}} \mathrm{T}_{\mathrm{S}}
$$

where $\mathrm{I}_{\mathrm{AV}}$ is the average of current in inductor $\mathrm{L}_{1}$ and $\mathrm{T}_{\mathrm{S}}$ is the switching period. Assuming no losses within the converters, it can be shown that

$$
\mathrm{Q}=\frac{\mathrm{P}_{\text {rated }}}{\mathrm{NV}_{\text {in }}} \mathrm{T}_{\mathrm{S}}
$$

where $P_{\text {rated }}$ is the rated power, $Q$ is the amount of charge in the switching period and $T_{S}=\left(1 / F_{S}\right)$. Hence,

$$
\mathrm{Q}=\frac{\mathrm{P}_{\text {rated }}}{\mathrm{NV}_{\text {in }} \mathrm{F}_{\mathrm{S}}}
$$

From Fig. 5(d), the charge transferred to stage 1capacitors results in a voltage change of $\Delta \mathrm{V}_{\mathrm{CJ}}$, which is given by; 


$$
\Delta \mathrm{V}_{\mathrm{C}(\mathrm{J})}=\frac{\mathrm{Q}}{\mathrm{C}_{\mathrm{eq}(\mathrm{J})}}
$$

Substituting for Q from equation (9) to equation (10) and rearranging;

$$
\mathrm{C}_{\mathrm{eq}(\mathrm{J})}=\left(\frac{\mathrm{P}_{\text {rated }}}{\mathrm{NV}_{\text {in }} \Delta \mathrm{V}_{\mathrm{C}(\mathrm{J})} \mathrm{F}_{\mathrm{S}}}\right)
$$

Hence,

$$
\left.\mathrm{C}_{\mathrm{J}}\right|_{\mathrm{j}=1, \mathrm{~J}}=\left(\frac{\mathrm{P}_{\text {rated }}}{\mathrm{NV}_{\text {in }} \Delta \mathrm{V}_{\mathrm{C}(\mathrm{J})} \mathrm{F}_{\mathrm{S}}}\right) \frac{1}{\mathrm{~J}}
$$

Substituting for $F_{S}$ from equation (6) into equation (9) and rearranging $L_{1}$ can be expressed as;

$$
\mathrm{L}_{1}=\frac{1}{\mathrm{C}_{\mathrm{eq}(\mathrm{J})}}\left[\frac{\mathrm{Q} \mathrm{NV}_{\text {in }}}{2 \pi \mathrm{P}_{\text {rated }}}\right]^{2}
$$

\section{Determination of stage 2 parameters}

Capacitance values in stage 1, 2 and 3 are chosen so that percent ripple on all the capacitors are the same. This means:

$$
\mathrm{C}_{\mathrm{K}}=\frac{\mathrm{C}_{\mathrm{J}}}{\mathrm{J}+\mathrm{K}+\mathrm{L}}
$$

In order to ensure soft switching the resonant frequency in the second sub-commutation must be made equal to $\omega$. Hence,

$$
\omega=\frac{1}{\sqrt{\mathrm{L}_{2}\left[\mathrm{C}_{\mathrm{eq}(\mathrm{J})}+\mathrm{C}_{\mathrm{eq}(\mathrm{K})}\right]}}
$$

where $\omega$ is the resonant Frequency of the converter and $\mathrm{C}_{\mathrm{eq}(\mathrm{K})}$ is the equivalent capacitance of both stages $C_{J}$ in series and $C_{K}$ in parallel. As shown in Fig.4, the number of capacitors in stage 2, $(\mathrm{K})$ are connected and charged by the number of series capacitors in stage $1(\mathrm{~J})$. Therefore, the equivalent capacitance of this state is given as;

$$
\mathrm{C}_{\mathrm{eq}}=\frac{\left(\mathrm{C}_{\mathrm{J}} / 2\right)\left(3 \mathrm{C}_{\mathrm{K}}\right)}{\left(\mathrm{C}_{\mathrm{J}} / 2\right)+\left(3 \mathrm{C}_{\mathrm{K}}\right)}
$$

By combining Equation (15) and (16), equation (17) can be written as:

$$
\mathrm{L}_{2}=\left(\frac{2 \mathrm{~K}^{\mathrm{n}}}{\mathrm{C}_{\mathrm{eq}(\mathrm{K})}}\right)\left(\frac{\mathrm{C}_{\mathrm{J}}}{\mathrm{J}^{\mathrm{n}}}\right)^{2}
$$

\section{Determination of stage 3 parameters}

The capacitors in stage 3 is given by equation (19), and in the same way of inductor $L_{2}$ was derived, Inductor $\mathrm{L}_{3}$ can be obtained as;

$$
\mathrm{L}_{3}=\left(\frac{2 \mathrm{~L}^{\mathrm{n}}}{\mathrm{C}_{\mathrm{eq}(\mathrm{L})}}\right)\left(\frac{\mathrm{C}_{\mathrm{K}}}{\mathrm{K}^{\mathrm{n}}}\right)^{2}
$$

and

$$
\mathrm{C}_{\mathrm{L}}=\frac{\mathrm{C}_{\mathrm{K}}}{\mathrm{J}+\mathrm{K}+\mathrm{L}}
$$


Although, two capacitors are shown in Fig. 2. In general, there can be $J$ capacitors. Therefore, capacitance in the stage 1 is denoted by $\mathrm{C}_{\mathrm{J}}$. Similarly, number of capacitor in the stage 2 and stage 3 are denoted by $\mathrm{C}_{\mathrm{K}}$ and $\mathrm{C}_{\mathrm{L}}$, respectively.

The relationship between ripple voltage and capacitor voltage in the first stage is the same in stages 2 and 3 , and can be shown as:

$$
\frac{\Delta \mathrm{VC}_{\mathrm{J}}}{\mathrm{VC}_{\mathrm{J}}}=\frac{\Delta \mathrm{VC}_{\mathrm{K}}}{\mathrm{VC}_{\mathrm{K}}}=\frac{\Delta \mathrm{VC}_{\mathrm{L}}}{\mathrm{VC}_{\mathrm{L}}}
$$

\section{Determination of output section parameters}

As illustrated in Fig. 4, the output stage is charged from $\left(t_{0}-t_{1}\right)$, and the electric charge in stage 3 is transferred in series to the output capacitor $\mathrm{C}_{\text {out }}$ through an output inductor $\mathrm{L}_{\text {out }}$ and an output diode $\mathrm{D}_{\text {out }}$. The size of the output inductor depends on the output voltage and the amount of charges that needs to be transferred. The value of output inductor depends on the peak-to-peak of output current $\Delta \mathrm{I}_{\text {Lout }}$ can therefore be expressed as;

$$
\mathrm{L}_{\text {out }}=\left(\frac{\mathrm{NV}_{\text {in }} \mathrm{T}_{\mathrm{s}}}{\Delta \mathrm{I}_{\text {Lout }}}\right)
$$

The output voltage waveform is not similar to the other voltage capacitor waveforms in the middle stage. Nevertheless, the value of the output capacitor depends on the relation between the amount of charge to the load at half period of time $\mathrm{T}_{\mathrm{S}} / 2$ and the voltage ripple on the output capacitor. Furthermore, the output capacitor works as charge storage for continuous delivery to the load. The equation can be written as:

$$
\mathrm{C}_{\text {out }}=\frac{\left(\mathrm{P}_{\text {rated }} / \mathrm{V}_{\text {out }}\right)\left(\mathrm{T}_{\mathrm{S} / 2}\right)}{2 \pi \Delta \mathrm{VC}_{\text {out }}}
$$

\section{Simulation studies}

The arrangement and location of the proposed converter is shown in Fig. 6, which forms the basis for the simulation study. In this topology, the cluster is formed by two parallel lines of wind turbines, each containing 5 wind turbines in series. Hence, there is a total of 10 wind turbines; each rated at 5 MW, $1.2 \mathrm{kV}$ [13],[14]. Therefore, the cluster bus voltage is $6 \mathrm{kV}$ and the rated power is $50 \mathrm{MW}$. The medium voltage (MV) DC-DC converter boosts the voltage from $6 \mathrm{kV}$ to $30 \mathrm{kV}$. A submarine cable is used to connect the MV converter platform to the main bus of the HV converter.



Fig. 6: Electrical system for the Grid Connection of a Windfarm 
The HV converter, whose equivalent circuit is shown in Fig. 2, was simulated by Matlab/Simulink software package. The converter parameters (Table II) were calculated using the design equations derived in the previous section.

\section{Table II: Parameters used for cascaded DC-DC converter simulation}

\begin{tabular}{|c|c|c|c|c|}
\hline \multicolumn{4}{|c|}{ Parameter } & Value/ model \\
\hline \multicolumn{2}{|c|}{ Number of stages } & \multicolumn{2}{|l|}{$\mathrm{n}$} & 3 \\
\hline \multicolumn{2}{|c|}{ Number of capacitors in each stage } & \multicolumn{2}{|l|}{ J K L } & $2,3,2$ \\
\hline \multicolumn{2}{|c|}{ Input Voltage } & \multicolumn{2}{|l|}{$\mathrm{V}_{\text {in }}$} & $30 \quad \mathrm{kV}$ \\
\hline \multicolumn{2}{|c|}{ Output Voltage } & \multicolumn{2}{|l|}{$\mathrm{V}_{\text {out }}$} & $360 \mathrm{kV}$ \\
\hline \multicolumn{2}{|c|}{ Load Current } & \multicolumn{2}{|l|}{$\mathrm{L}_{\text {out }}$} & $138.89 \mathrm{~A}$ \\
\hline \multicolumn{2}{|c|}{ Rated power } & \multicolumn{2}{|l|}{$\mathrm{P}_{\text {rated }}$} & $50 \mathrm{MW}$ \\
\hline \multicolumn{2}{|c|}{ Switching Frequency } & \multicolumn{2}{|l|}{$\mathrm{F}_{\mathrm{S}}$} & $2 \mathrm{kHz}$ \\
\hline \multicolumn{2}{|c|}{ Output Load Resistance } & \multicolumn{2}{|l|}{$\mathrm{R}_{\text {Load }}$} & $2592 \Omega$ \\
\hline \multicolumn{4}{|c|}{ IGBT } & 5SNA 1200G450300 \\
\hline \multicolumn{4}{|c|}{ Fast recovery diode } & 5SDF13H4501 \\
\hline \multicolumn{3}{|c|}{ Capacitors } & \multicolumn{2}{|c|}{ Inductors } \\
\hline $\mathrm{C}_{\mathrm{J}}$ & $694.5 \mu \mathrm{F}$ & & $\mathrm{L}_{1}$ & $5.3 \mu \mathrm{H}$ \\
\hline $\mathrm{C}_{\mathrm{K}}$ & $99.21 \mu \mathrm{F}$ & & $\mathrm{L}_{2}$ & $40 \mu \mathrm{H}$ \\
\hline $\mathrm{C}_{\mathrm{L}}$ & $14.17 \mu \mathrm{F}$ & & $\mathrm{L}_{3}$ & $400 \mu \mathrm{H}$ \\
\hline $\mathrm{C}_{\mathrm{o}}$ & $300 \mu \mathrm{F}$ & & $\overline{\mathrm{L}_{\text {out }}}$ & $2.2 \mathrm{mH}$ \\
\hline
\end{tabular}

Current waveforms in Fig. 7(a) shows the resonant nature of the currents through inductors and IGBTs allowing soft switching at current zeros leading to a reduction in switching losses. Figure 7(b) shows the switching signals clearly indicating soft switching at a frequency of $2 \mathrm{kHz}$.



Fig. 7: Matlab / Simulink Simulation results. a) Inductor current waveforms (ZCS), b) switching pattern

Fig. 8 shows the load voltage and current waveforms confirming that the design specifications are met. The DC amplification gain of the simulation is 11.96, which is very close to the design value of 12 . The resonating inductor current, which flows through the IGBT increases to a peak $\mathrm{I}_{\mathrm{L} 1}=35 \mathrm{KA}$ in 250 $\mu \mathrm{s}$, which is within the capability of modern IGBTs [15]. As seen from Fig. 7, the respective peak inductor currents in consequent stages decrease according to the number of capacitors in the previous stage. The effect can be generalised as shown in Table III. The proposed cascaded configuration is evaluated and compared with Veilleux converter in terms of the power device count to highlight its advantages in high-voltage applications. The high voltage with a maximum blocking voltage rated up the ratings of the IGBT considered for this study are $4.5 \mathrm{kV}$ and $1200 \mathrm{~A}$. The total number of IGBTs 
can be reduced from 52 to 38 by combining the function of 2 IGBT switches $\left(\mathrm{S}_{\mathrm{P} 2}-\mathrm{S}_{\mathrm{P} 3}\right)$ to be performed by 2 diodes and 1 IGBT (Svalve) as illustrated in the yellow circle in Fig.2.
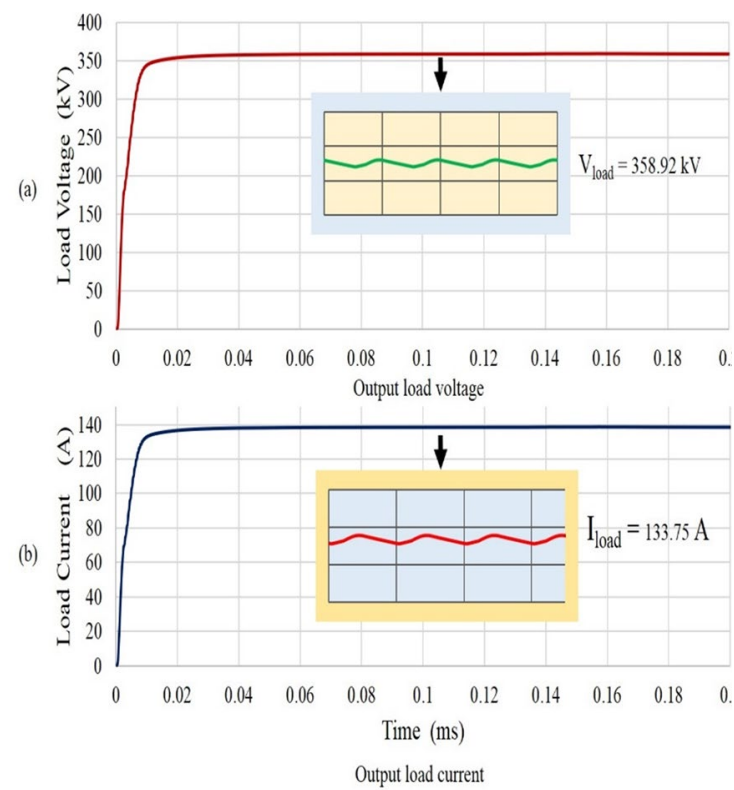

Fig. 8: Simulation waveforms of the improved topology



Fig. 9: Simulation results Capacitor voltage waveforms

Table III: shows the peak inductor currents and voltage across capacitors

\begin{tabular}{|l|c|c|c|c|}
\hline \multicolumn{1}{|c|}{ Parameters } & Stage 1 & Stage 2 & Stage 3 & Output section \\
\hline Number of capacitors & 2 & 3 & 2 & 1 \\
\hline $\begin{array}{l}\text { Peak inductor currents } \\
\text { relation }\end{array}$ & $I_{L 1}$ & $I_{L 2}=I_{L 1} / 2$ & $I_{L 3}=I_{L 2} / 3$ & $I_{\text {Lout }}=I_{L 3} / 2$ \\
\hline Number of stages & $J$ & $K$ & $L$ & $L_{\text {out }}$ \\
\hline Peak inductor currents & $I_{L 1}^{P}$ & $I_{L 2}^{P}=I_{L 1}^{P} / J$ & $I_{L 3}^{P}=I_{L 2}^{P} / K$ & $I_{\text {out }}^{P}=I_{L 3}^{P} / L$ \\
\hline Voltage cross capacitors & $V_{C 1}=V_{C 2}=V_{\text {in }}$ & $\begin{array}{c}V_{C 3}=V_{C 4}=V_{C 5}= \\
J V_{\text {in }}\end{array}$ & $\begin{array}{c}V_{C 6}=V_{C 7}= \\
J K V_{\text {in }}\end{array}$ & $V_{\text {out }}=J K L V_{\text {in }}$ \\
\hline
\end{tabular}

As shown in Fig. 9, the average DC voltages a cross capacitors increase and their values depend of the number of capacitors in each stage as depicted in the Table III. Capacitor voltage in stage 1, stage 2, and stage 3 is charging by $29.97 \mathrm{kV}, 59.69 \mathrm{kV}$ and $179.47 \mathrm{kV}$, respectively. The discrepancy between design charging voltage and simulation results is mainly due to small resistance of the IGBT switches and diodes, which have been omitted in the mathematical analysis equations but it is included in the simulation.

Fig. 10 shows that the output voltage in the improved converter is higher than that of Veilleux converter, but both topologies perform equally well. Several HV DC-DC topologies that have a high gain ration, but not always with reduced number of semiconductor component as one of the major goals. Therefore, the improved topology concentrated on reducing the number of devices.

The total number of devices for varying voltage gains are shown in Fig. 11 that shows the device count comparison with different gains between the Veilleux Cascaded converter and the improved cascaded converter. For both configuration, IGBT switches are comprised of several series connected power devices to withstand the rated voltage.

Fig. 11 shows the comparison of designs to give voltage gains of 1:12, 1:27, and 1:36. The number of reduces by $27 \%, 30 \%$ and $37 \%$ as the gain increases by 12,27 , and 36 , respectively. However, the diode count increases by a small margin. However, diodes are cheaper and easy to connect in series. 


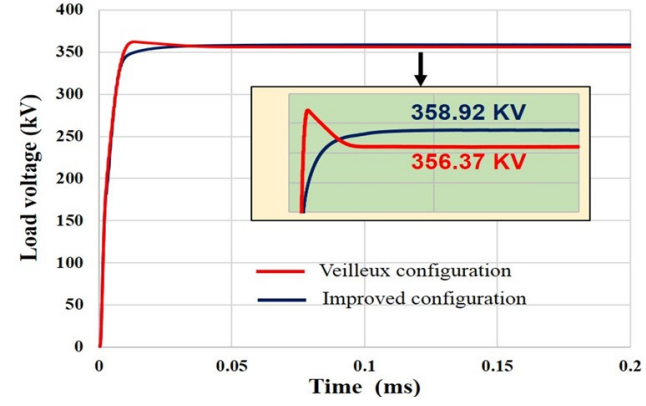

Fig. 10: Load voltage comparisons between Veilleux converter and improved converter

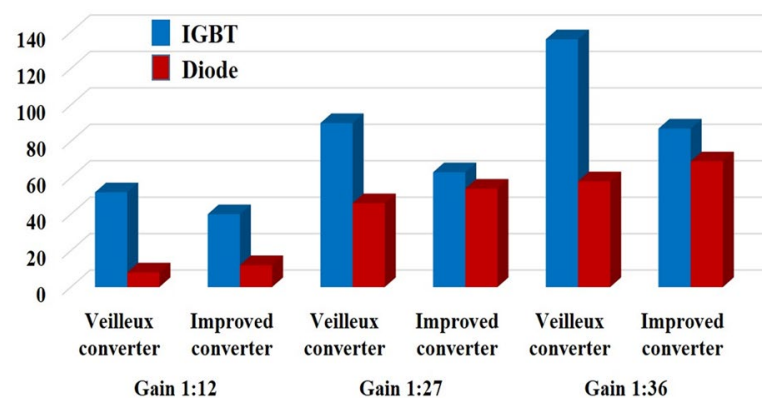

Fig. 11: Components count for DC-DC converter topologies comparisons between Veilleux converter and improved converter

\section{Conclusions}

In this paper, the analysis, design and simulation of a high voltage cascaded DC-DC converter using a multi-stage topology suitable for HVDC offshore wind farm applications is presented. This converter can achieves gain with reduced components. The reduction increases with the increase in voltage gain. Soft switching can be implemented and a method for calculating the resonant component values and the switching frequency is given. A design methodology and equations for the determination of the circuit components and solid-state devices is presented. The theoretical predictions have been confirmed by the simulations.

\section{References}

[1] S. M. Alagab, S. Tennakoon, and C. Gould.: Review of wind farm power collection schemes, staffordshire University. Power Eng. UPEC Conf., vol. 2015-Novem, 2015.

[2] M. H. Johnson, D. C. Aliprantis, and H. Chen.: Offshore wind farm with DC collection system, 2013 IEEE Power Energy Conf. Illinois, PECI 2013, pp. 53-59, 2013.

[3] I. Laird and D. D. C. Lu.: High step-up DC/DC topology and MPPT algorithm for use with a thermoelectric generator, IEEE Trans. Power Electron., vol. 28, no. 7, pp. 3147-3157, 2013.

[4] Xuefeng Hu and Chunying Gong.: A High Voltage Gain DC-DC Converter Integrating Coupled-Inductor and Diode\&amp; IEEE Trans. Power Electron., vol. 29, no. 2, pp. 789-800, 2014.

[5] T. Nouri, S. H. Hosseini, E. Babaei, and J. Ebrahimi.: A non-isolated three-phase high step-up DC-DC converter suitable for renewable energy systems, Electr. Power Syst. Res., vol. 140, pp. 209-224, 2016.

[6] Y. P. Siwakoti, F. Blaabjerg, and P. C. Loh.: High Step-Up Trans-Inverse (Tx -1 ) DC-DC Converter for the Distributed Generation System, IEEE Trans. Ind. Electron., vol. 63, no. 7, pp. 4278-4291, 2016.

[7] A. Parastar.: High Power Step-up Modular Resonant Converter , pp. 3341-3348, 2014.

[8] J. A. Ferreira.: The multilevel modular DC converter, IEEE Trans. vol. 28, no. 10, pp. 4460-4465, 2013.

[9] X. Zhang and T. C. Green.: The New Family of High Step Ratio Modular Multilevel DC-DC Converters, vol. 2, pp. 1743-1750, 2015.

[10] J. Maneiro, S. Tennakoon, and C. Barker.: Scalable shunt connected HVDC tap using the DC transformer concept, 2014 16th Eur. Conf. Power Electron. Appl. EPE-ECCE Eur. 2014, pp. 6-8, 2014.

[11] P. W. Lehn, B.-T. Ooi, and E. Veilleux.: Marx dc-dc converter for high-power application, IET Power Electron., vol. 6, no. April, pp. 1733-1741, 2013.

[12] E. Veilleux and B. T. Ooi.: Marx-dc-dc converter for connecting offshore wind farms to multiterminal HVDC, IEEE Power Energy Soc. Gen. Meet., pp. 1-5, 2013.

[13] P. Lakshmanan, J. Liang, and N. Jenkins.: Assessment of collection systems for HVDC connected offshore wind farms, Electr. Power Syst. Res., vol. 129, pp. 75-82, Dec. 2015.

[14] S. M. Alagab, S. B. Tennakoon, and C. A. Gould.: A Compact DC-DC Converter for Offshore Wind Farm Application, Renew. Energy Power Qual. J., vol. 1, no. 15, pp. 529-533, 2017.

[15] ABB.: Surge currents for IGBT diodes, 2014. 